Branislava Knežićl,

Maja Savić2

UDK: $374.7-058.5(497.11)$

$343.81(497.11)$

\title{
OBRAZOVANJE U ZATVORU: OD PRAVA DO REALIZACIJE ${ }^{3}$
}

\section{- Sažetak -}

Porast broja povratnika, prenatrpanost zatvora $i$ loši uslovi u njima ne ulivaju nadu da se društvo na najbolji način suočava sa problemima kriminaliteta. Od osamdesetih godina prošlog veka, u većini zapadnih zemalja $i$ kod nas, na udaru kritike našao se koncept resocijalizacije jer se smatra da nije doveo do smanjenja ukupnog kriminaliteta i recidivizma. Problem sa kojim se društva suočavaju je kako u zatvorskoj sredini pripremiti osuđenika da se uspešno integriše u društvenu zajednicu po izlasku iz zatvora. Veoma važnu ulogu u realizaciji ovog cilja može imati obrazovanje. U članku ćemo se baviti različitim aspektima obrazovanja u zatvoru: kako ga država propisuje $i$ kako vidi njegovu svrhu, kakvo je aktuelno stanje u realizaciji prava na obrazovanje u nekim zemljama sveta $i$ kod nas, koje su prepreke u realizaciji obrazovanja u zatvorima. Jedan od glavnih preduslova za implementaciju $i$ uspeh obrazovnih programa u zatvoru jeste i motivacija samih osudenika da se uključe u njih. Prikazaćemo deo empirijskog istraživanja sprovedenog na prigodnom uzorku iz dva KPZ (Požarevac i Sremska Mitrovica) o motivaciji osuđenika za obrazovanjem i obrazovnim potrebama.

1 Dr. Branislava Knežić je vanredni profesor na Odeljenju za pedagogiju i andragogiju Filozofskog fakulteta Univerziteta u Beogradu, naučni savetnik Instituta za kriminološka i sociološka istraživanja u Beogradu.

2 Dr. Maja Savić je docent na Filološkom fakultetu Univerziteta u Beogradu, naučni saradnik Instituta za kriminološka i sociološka istraživanja u Beogradu.

3 Članak je uz odobrenje autorica, preuzet iz časopisa „Andragoške studije” I/2013 i predstavlja rezultat rada na projektu „Kriminal u Srbiji:fenomenologija, rizici i mogućnosti socijalne intervencije" (br. 47011) koji finansira Ministarstvo prosvete, nauke i tehnološkog razvoja Republike Srbije (2011-2014). 
Ključne reči: obrazovanje, zatvorenici, recidivizam, resocijalizacija, zatvorska sredina.

Uprkos manjkavostima izvora podataka i metodološkim teškoćama u njihovom prikupljanju u različitim zemljama, postojeći podaci pokazuju da je opšti trend u svetu uvećanje zatvorske populacije. Stopa zatvaranja porasla je u 78\% zemalja sveta - 71\% zemalja u Africi, $82 \%$ u Americi, $80 \%$ u Aziji, 74\% u Evropi i 80\% u Okeaniji (Walmsley, 2012). U Evropskoj uniji je u periodu 1995-2009. broj osuđenika porastao za 24\% (European Comission, 2010), a u Srbiji u periodu 2005-2010. za 30\% (Helsinški odbor za ljudska prava u Srbiji, 2010). Ovakvo značajno povećanje zatvorske populacije stavlja države i društva pred ozbiljne izazove, s jedne strane finansijske jer predstavlja dodatno opterećenje državnog budžeta, a s druge strane društvene, jer raste broj ljudi koje je potrebno na neki način resocijalizovati i integrisati na funkcionalan način u društvo.

Pitanje je da li zatvori i tretmani onakvi kakvi su mogu ispuniti svrhu kažnjavanja kako je zakon određuje: „Svrha izvršenja kazne zatvora je da osuđeni tokom izvršenja kazne, primenom odgovarajućih programa postupanja, usvoji društveno prihvatljive vrednosti u cilju lakšeg uključivanja u uslove života posle izvršenja kazne kako ubuduće ne bi činio krivično delo,, (čl. 31. Izmene ZIKS RS). Ne samo normativna akta nego i stručna literatura nije jednoglasna i nije lišena pojmovne zbrke u brojnim pokušajima definisanja svrhe izvršenja zatvorske kazne. Insistiranje na preciznosti određenja termina: resocijalizacija, prevaspitavanje, reintegracija, popravljanje, osposobljavanje za istraživače u ovoj oblasti je manji problem od načina kako se taj proces organizuje, ko ga sprovodi i kojim metodama i sadržajima. Prema našem uverenju pravo pitanje bi bilo da li su aktivnosti usklađene sa potrebama i mogućnostima cilja kažnjavanja i na koji način se obrazovanje uklapa u njih.

Poznato je da zatvorski tretman u većini zemalja počiva na radnim obavezama i obrazovnim programima ${ }^{4}$. Evropska zatvorska pravila ${ }^{5}$ posvećena obrazovanju zatvorenika sadrže 7 članova od kojih izdvajamo: 28.1 „Svaki zatvor treba da nastoji da svim zatvorenicima omogući pristup obrazovnim programima koji su što je moguće sveobuhvatniji i koji zadovoljavaju njihove individualne potrebe, istovremeno vodeći računa o njihovim težnjama,,, 28.2 „Prioritet imaju zatvorenici koji su nepismeni ili oni koji nemaju osnovno ili

4 U okviru Obrazovnog programa Sokrat Evropske unije pokrenuta je šira evropska mreža za obrazovanje u zatvoru kako bi proširila aktivnosti.

5 Preporuka Rec (2006) 2 Komiteta ministara država članica u vezi sa evropskim zatvorskim pravilima, koju je usvojio Komitet ministara 11. januara 2006. na 952. sednici zamenika ministara. 
vokaciono obrazovanje,, i 28.3 „Posebna pažnja poklanja se obrazovanju mlađih zatvorenika i zatvorenika s posebnim potrebama,..

Naše zakonodavstvo takođe propisuje pravo na obrazovanje u zatvoru, ZIKS čl. 110: „Osuđeni ima pravo na osnovno i srednje obrazovanje, koje se shodno opštim propisima organizuje u zavodu. Zavod organizuje i druge vidove obrazovanja,,

Zbog potreba usklađivanja sa evropskim pravnim standardima i preporukama Saveta Evrope unete su promene i donet je zakon o izmenama i dopunama Zakona o izvršenju krivičnih sankcija (Sl. glasnik RS, br.72/09). Zakonske odredbe pružaju dovoljan okvir za osposobljavanje osuđenih u cilju uspešne integracije u društvo i život na slobodi, ali neophodan je suštinski, a ne deklarativni stav društva prema tretmanu u zatvorima.

Bez obzira na to koliko je zatvorska sredina veštački ambijent opasan zidovima i raznovrsnim ograničenjima proizvešće manje deprivacije i štetne posledice po osuđenike, ako vreme provedeno u zatvoru bude smislenije od „treniranja strogoće,,, prebrojavanja, cinkarenja, obavljanja raznih besciljnih zadataka, ispraznog slobodnog vremena i sl. Proces i aktivnost koja može da bude važna poluga promene na individualnom (ličnost, ponašanje, kvalitet života osuđenika) i društvenom planu je obrazovanje, ali da bi ono zaista postalo faktor promene potrebno je da njegov značaj i potencijal nedvosmisleno prepoznaju i država (ne samo formalno) i sami osuđenici.

Društva daleko bogatija od našeg imaju problem sa finansiranjem edukativnih programa u zatvorima. Upravo je smanjenje finansiranja ovakvih programa u Americi, navelo istraživače da intenzivnije prate efekte ranije postojećih obrazovnih programa na recidivizam i uspešnost resocijalizacije, kako bi uverili finansijere da je investicija u obrazovanje dugoročno manji trošak za državu. Smanjenje recidivizma pre svega znači smanjenje kriminala, viktimizacije, ali i smanjenje troškova hapšenja, suđenja i zatvorskog života za povratnike.

U SAD i nekim od zemalja EU gde postoji višedecenijska praksa sprovođenja edukativnih programa u zatvorima, rađena su istraživanja koja su pratila efekte zatvorskog obrazovanja na smanjenje recidivizma i uspešniju resocijalizaciju osuđenih lica. Istraživanja su pokazala da su zatvorenici koji pohađaju edukativne programe manje skloni da se vrate u zatvor, tj. da obrazovanje u zatvoru može da utiče na smanjenje recidivizma (Harer, 1994, 1995; Cecil et al., 2000; Hull et al, 2000; Steurer \& Smith, 2003; Vacca, 2004; MacKenzie, 2006). Pokazano je da se smanjuje i nivo nasilničkog ponašanja (Vacca, 2004), kao i broj disciplinskih problema osoba koje učestvuju u 
zatvorskim edukativnim programima (Kling, 2006). Bozos i Hausman (Bozos \& Hausman, 2004) navode da za zatvorenike, koji su prošli neki vid edukacije u zatvoru, postoji 10-20\% manja verovatnoća da će se ponovo vratiti u zatvor u odnosu na one koji nisu učestvovali u edukaciji, dok se u studiji Steurera i Smita (Steurer \& Smith, 2003) navodi da je recidivizam kod osuđenika koji su učestvovali u edukativnim programima za $29 \%$ manji nego kod onih koji nisu. Neki istraživači (Gehring, 2000; Lewis, 2006; Wade, 2007, prema Gaes, 2008) ističu da dobijeni efekti obrazovanja na recidivizam zavise od načina na koji se on meri, od tipova edukativnih programa čiji se efekti prate, kao i od izbora dobrih mera tih programa.

Uprkos donekle skromnijim efektima obrazovanja na recidivizam u odnosu na uložena očekivanja, njegova uloga za pojedince u zatvoru i za društvo u celini ne sme se potceniti.

Države imaju različiti pristup realizaciji obrazovanja u zatvorima. U Francuskoj su obrazovanjem obuhvaćeni samo osuđenici koji su zainteresovani. U Italiji postoji niz mera koje stimulišu srednje i visoko obrazovanje; obrazovne aktivnosti zasnovane su na dobrovoljnom učešću osuđenika, ali onaj koji je aktivno učestvovao u programu reedukacije ima priliku da bude ranije pušten iz zatvora. U Nemačkoj se u okviru socijalne službe u zatvorima ostvaruju ciljevi tretmana u procesu korekcije osuđenikovog ponašanja i služba ima visok stepen samostalnosti i uživa veliki ugled. i u Austriji obrazovanje i profesionalno osposobljavanje zauzima vidno mesto u tretmanu osuđenih lica (školovanje za stručnog radnika, pohađanje stručnih kurseva, nastavak školovanja van zatvora, dopisni kursevi, nastava za učenike, kao i drugi vidovi obrazovanja osuđenika). U poslednje vreme organizuju se razni kursevi za rad na kompjuterima i te diplome su priznate u celoj EU. U zatvorima u Holandiji primenjuju se različiti oblici tretmana, među njima i obrazovanje što zavisi od kategorije zatvorenika i njihovih karakteristika. U ruskim korektivnim ustanovama zatvorenici mogu da ostvare svoje pravo na opšte osnovno i stručno obrazovanje, a omogućeno im je učenje na daljinu i dopisni kursevi. U Hrvatskoj je obrazovanje jedan od bitnijih vidova tretmana iako se poslednjih godina sve manji broj osuđenika odlučuje za nastavak obrazovanja (Stevanović, 2012). Obrazovanje i stručno osposobljavanje u švedskim zatvorima je prilično razvijeno i prati savremene tendencije koje se kreću u pravcu iznalaženja novih oblika i metoda u radu sa zatvorenicima. Važna karakteristika obrazovanja u švedskim zatvorima jeste da je ono sastavni deo redovnog obrazovanja odraslih, što omogućava zatvorenicima da nastave započetu edukaciju po izlasku iz zatvora i da sa 
diplomom stečenom u zatvoru budu konkurentni prilikom traženja posla. Ključno sredstvo u obrazovnim aktivnostima danas je kompjuterizovana platforma pod nazivom Netcentar koji omogućava svakom zatvoreniku da na osnovu svojih planova i ciljeva bira kurseve koji mu odgovaraju (Kosmidou, 2011). To znači da putem ove platforme zatvorenik može da prati i polaže kurseve koji nisu u ponudi obrazovnih programa u zatvoru u kojem je smešten, ali da može da dobije obrazovnu podršku od lokalnih nastavnika i predavača ukoliko mu je potrebna. Ovakvo studiranje povećava dostupnost obrazovanja i omogućava individualizovaniji pristup obrazovanju. Važno je istaći da su ciljevi obrazovanja usmereni na razvijanje kompetenci zatvorenika, pomoć i pripremu za nastavak školovanja nakon zatvora ili dobijanje posla, ali i na razvijanje neformalnih kompetenci kao što su preuzimanje odgovornosti, učešće u timskom radu i funkcionisanje u grupi, koje im pomažu da zadrže posao i utiču na poboljšanje kvaliteta života (Kosmidou, 2011).

Pored toga što edukativni programi omogućavaju sticanje konkretnih znanja i veština koje osposobljavaju ljude za zapošljavanje po izlasku iz zatvora, smatra se da im oni omogućavaju i sticanje nekih novih socijalnih veština i usvajanje prosocijalnih normi važnih za reintegraciju u društvo. Ripli (Ripley, 1993) navodi da recidivizam opada upravo kada su edukativni programi kreirani tako da razvijaju socijalne veštine, podstiču umetničko izražavanje i usvajanje tehnika i strategija za regulisanje vlastitih emocija. Ovaj autor takođe ističe važnost moralnog obrazovanja i razvijanja kritičkog mišljenja i rešavanja problema u edukativnim programima. Učestvujući u ovakvim programima zatvorenici na produktivan način koriste vreme provedeno u zatvoru, a usvajanje novih veština doprinosi njihovom osećanju samopoštovanja i postignuća.

Uspešan obrazovni proces je kompleksan, jer zahteva kontinuitet i ulaganje i ljudskih i materijalnih resursa. S jedne strane postoji zahtev da se taj proces individualizuje i prilagodi potrebama i mogućnostima zatvorenika, a s druge strane da se realizuje u okolnostima povećanog nadzora i ograničenog pristupa resursima (kompjuteri, Internet, biblioteke, materijal za rad). Ova dva zahteva su često u suprotnosti što može dovesti do prepreka i teškoća u realizaciji obrazovnih programa.

Prepreke u realizaciji obrazovanja u zatvoru mogu poticati od samih zatvorenika ili od okolnosti u kojima se realizuje ili institucije koja ga realizuje, pa tako razlikujemo:

- Dispozicione prepreke koje su vezane za samog zatvorenika i posledica su njegovih iskustava za vreme ili posle izdržavanja kazne: 
problematično detinjstvo, neuspeh u školi, nisko samopouzdanje, zloupotreba droge i alkohola, problemi u komunikaciji, učenju ili mentalnom zdravlju).

- Institucionalne i situacione prepreke koje ne zavise od zatvorenika, a u koje spadaju: premeštanje iz jednog zatvora u drugi, odsustvo biblioteka, odsustvo ili oduzimanje pisanog edukativnog materijala, dugo čekanje na mogućnost da započnu kurs, ograničena mogućnost ili potpuno odsustvo mogućnosti da se obuče za rad na računaru; nizak kvalitet obuke; suviše bazičan, neodgovarajući i irelevantan sadržaj obuke, neosetljivost na posebne potrebe onih koji uče, uskraćivanje edukativnih ,privilegija,, kao kaznena mera, nedostatak novca za finansiranje visokog obrazovanja, uskraćivanje prava na obrazovanje u zavisnosti od mesta izdržavanja kazne, dužine kazne i sigurnosne kategorije (UN Human Rights Council, 2009; GHK, 2011).

Jedan od glavnih preduslova zaimplementacijui uspeh obrazovnih programa u zatvoru jeste motivacija samih osuđenika da se uključe u njih. Učešće, motivi i potrebe odraslih za obrazovanjem predmet su mnogih istraživanja i rasprava u naukama koje se bave obrazovanjem odraslih. Navodimo rezultate Bošijea (Boshier, 1985), autora jednog od najpoznatijih radova u andragoškoj literaturi o razlozima participacije odraslih u obrazovanju. Autor ističe da odrasli učestvuju u obrazovnim delatnostima iz sledećih razloga:

- potrebe za socijalnim kontaktom,

- potrebe za socijalnom stimulacijom,

- potrebe za profesionalnim napredovanjem,

- potrebe služenja zajednici,

- potrebe zbog spoljnih očekivanja,

- kognitivnih interesa.

Moglo bi se konstatovati da se odrastao čovek odlučuje za proces obrazovanja iz tri razloga: da bi zadovoljio društvenu sredinu, zadovoljio sebe i dobio poštovanje od drugih. Drugim rečima, odrastao čovek uči da bi znao: raditi, živeti zajedno s drugima i da bi „znao”. Ako se na trenutak zaborave specifični uslovi zatvora kao obrazovne sredine može se reći da i osuđenici imaju iste želje i potrebe za obrazovanjem.

Specifičnost obrazovanja odraslih, za razliku od dece, ogleda se u tome što biraju i sami odlučuju o tome šta žele da uče, u zavisnosti od toga kako vide sebe i da li žele da uče od drugih odraslih. U skladu sa tim, obrazovanje u zatvoru ne počiva toliko na autoritetu koliko na pristanku koji je jako teško 
ostvariti u prinudnom i autoritarnom okruženju kakav je zatvor. Sofer (Soferr, 2006) smatra da su osuđenici ljudi sa bogatim životnim iskustvom koje za njih - iako problematično i različito od iskustva običnih ljudi - predstavlja znanje o svetu oko njih. Opremljeni ovim znanjem često su skloni da odbijaju nova znanja i opiru se pokušajima da ih drugi uvere u suprotno. Prema Soferu pravi izazov za one koji se bave obrazovanjem u zatvoru, pored realizacije obrazovnih programa, je i uvođenje novih znanja, ali na takav način da podstiču želju za promenom i razvojem celokupne ličnosti.

O motivima uključivanja zatvorenika u obrazovne programe govori nam istraživanje Petre Mekginis (Petra MacGuinness, prema Wilson, Reuss, 2000) sprovedeno u muškom zatvoru Whitemoor u Velikoj Britaniji, u okviru obrazovnog odeljenja koje nudi programe od osnovnih veština do univerzitetskog nivoa (Open University studies). Na osnovu podataka koje je prikupila putem upitnika i polustrukturisanih intervjua Mekginisova izdvaja četiri grupe motiva:

1. Da nadoknade ono što su propustili u prvobitnom obrazovanju $(53,6 \%)$ - pošto su mnogi od zatvorenika slične dobi i sličnog socijalnog porekla lakše prihvataju pokušaj da nastave formalno obrazovanje nego što bi to bilo van zatvora;

2. Da bi se zanimali nečim, razbijanje dosade (21\%);

3. Da bi povećali mogućnost za zapošljavanje (13\%);

4. Da bi preživeli zatvor i ispunili vreme.

Ovi nalazi su zanimljivi jer nam govore da su osuđenici svesni društvenog vrednovanja obrazovanja i da je to i najjači motiv za uključivanje u njega.

\section{Obrazovanje u zatvorima u Srbiji}

Pokušaćemo ukratko da damo pregled stanja obrazovanja u zatvorima u Srbiji. Obrazovanje, obuka, kvalifikacija, prekvalifikacija i rad imaju, bar zakonski, bitnu ulogu u tretmanu izvršenja krivičnih sankcija u Srbiji. Međutim, u realizaciji obrazovnih programa zatvorske uprave i osoblje suočavaju se sa brojnim problemima i izazovima jer su prostorni, kadrovski i materijalni uslovi u zatvorima nezadovoljavajući. Zatvori su popunjeni daleko preko svojih kapaciteta, nedostaju materijalna sredstava za modernizaciju i pokretanje proizvodnje, za nabavku opreme i materijala, nedovoljno je sredstava za angažovanje nastavnika, nedostaju pojedini profili stručnjaka za obuku, ugašeno je obrazovanje koje je postojalo do pre dvadesetak godina, jak je uticaj neformalnih grupa u zatvoru, niska je motivisanost osuđenika, 
ali i osoblja za adekvatniju obuku, obrazovanje i organizovanje raznovrsnih tečajeva, predavanja, razgovora, tribina i sl. Prisutno je i potcenjivanje uticaja određenih oblika i vrsta tretmana, a ponekad i stav da samo represija može „slomiti,, počinioce krivičnih dela.

Do kraja osamdesetih godina prošlog veka u zatvorima u Srbiji obrazovanju se pridavao daleko veći značaj nego danas. Kazneno popravni zavodi u Nišu, Požarevcu i Sremskoj Mitrovici imali su obrazovne centre - škole za osnovno i srednje obrazovanje odraslih osuđenika. Škole su bile povezane sa odgovarajućim školama u gradu čime je zadovoljena zakonska obaveza da se iz diploma ne vidi da je osuđenik završio školu u toku izdržavanja kazne. Za vreme postojanja tih centara godišnje je upisivano više stotina osuđenika koji su završavali osnovno i srednje obrazovanje. Nakon toga nastaje sve manje interesovanje za obrazovanje čemu je prethodila sumnja u moć obrazovanja kao oblika tretmana u resocijalizaciji osuđenih i nezainteresovanost uprava zavoda za organizovanjem obrazovanja. Krajem dvadesetog veka u našim KPZ-ima opštim i stručnim obrazovanjem bilo je obuhvaćena oko trećina osuđenika u muškim zatvorima, a gotovo polovina ispitanih je izjavila da bi rado učestvovala u različitim kursevima, tečajevima i predavanjima. Žene ni u tom periodu, zbog malog broja, nisu bile obuhvaćene obrazovanjem iako ih je skoro 40\% bilo nepismeno (Knežić, 2001).

Pravilnikom o organizaciji i sistematizaciji radnih mesta u Upravi za izvršenje zavodskih sankcija (UIZS) iz 2006. godine postojeće škole u KPZ su postale odseci u Službi za prevaspitanje, najčešće sa jednim referentom za organizaciju kulturno-obrazovnih aktivnosti. Ovaj podatak dovoljno govori o tome kako naše društvo vidi ulogu i značaj obrazovanja kao faktora osposobljavanja osuđenih lica za integraciju u zajednicu po izdržanoj zatvorskoj kazni. Učešće osuđenika u edukativnim programima u KPZ-ima u Srbiji se u poslednjih dvadesetak godina kreće od 1-3\%. U KPZ Sremska Mitrovica postoji mogućnost osnovnoškolskog i srednjoškolskog obrazovanja, ali osuđenici u veoma malom broju koriste ove mogućnosti. Prema podacima Helsinškog odbora za ljudska prava (2010) preko 200 osuđenika (od ukupno 1764) ima potrebu za osnovnoškolskim obrazovanjem, ali je samo $10 \%$ njih uključeno u ovaj vid školovanja. Situacija sa srednjoškolskim obrazovanjem je još lošija, 514 osuđenika je bez srednje škole, a samo njih 15 pohađa srednju tehničku školu. Obrazovna struktura osuđenika gde je potpuno nepismenih $2,8 \%$, bez potpune osnovne škole $15,2 \%$, s osnovnom školom $26,5 \%$ i nedovršenom srednjom školom $6,6 \%$ ukazuje na potrebu za funkcionalnim osnovnim obrazovanjem odraslih i dokvalifikacijama i prekvalifikacijama. 
I ne samo obrazovna nego i starosna struktura osuđenika, gde je 68,5\% osuđenika starosti između 21 i 40 godina, upućuje na neophodnost takvih oblika obrazovanja.

$\mathrm{Na}$ osnovu podataka (UIZS) za 2011. godinu u srpskim zatvorima obrazovnim programima bilo je obuhvaćeno samo 316 osuđenika i 9 osuđenica što je oko $4 \%$ od ukupnog broja. Opismenjeno je 49 ili $0,7 \%$ lica; osnovnu školu završilo je 45 ili $0,6 \%$; tečajeve je pohađalo 167 ili oko $2 \%$ muškaraca i ni jedna žena; manje od 1\% (64) muškaraca je završilo treći stepen SSS i ponovo nijedna osuđenica. I tu, na sreću, nije kraj obrazovanju osuđenika kao organizovanom obliku tretmana. Krajem 2012. godine, u okviru projekta „Podrška stručnom obrazovanju i obuci u zatvorskim ustanovama Srbije,, počele su obuke u Požarevcu, Nišu i Sremskoj Mitrovici u kojima se sprovodi pilot VET obuke. Oko pet stotina osuđenika iz navedenih zatvora dobilo je priliku da odabere jedno od pet zanimanja: zavarivanje, štampanje sito štampom, obrada drveta i izrada pločastog nameštaja, izrada raznih vrsta pekarskih proizvoda i proizvodnja ranog voća i povrća u zaštićenom prostoru. Odabrana zanimanja su već dugo deficitarna na tržištu rada u Srbiji i obuka će se sprovoditi do septembra 2013. godine. Na osnovu prvih izveštaja broj osuđenih koji su zainteresovani za obuku se povećava i dobar primer je osuđenika iz KPZ Niš, koji je odbio da traži smanjenje kazne da bi završio obuku koju je započeo (www.vet-kpz.rs ).

Očekujemo da će pilot VET obuke prerasti u stalan proces i da će osuđenici koji nemaju nikakvo zanimanje dobiti mogućnosti obuke za konkretna zanimanja kao i za dokvalifikacije i prekvalifikacije. Na taj način bi se obrazovanjem i obukom osposobili, kvalifikovali, prekvalifikovali ili dokvalifikovali za neki posao i time osnažili za samostalan život. Poznato je da zatvor, bez smislenog i dobro organizovanog obrazovanja i obuke, često produbljuje uslove da osuđenici po izlasku na slobodu nastave sa onim zbog čega su i dospeli u zatvor. Po rečima mnogih osoba na izdržavanju zatvorske kazne zatvor predstavlja ,školu života, gde se stiču i usavršavaju mnogi „zanati,, i gde se „mentori,, nameću po jačini kriminalnog iskustva. Mnogima, u poslednjih dvadesetak godina, ništa drugo nije ni preostajalo nego da usavrše ono zbog čega su se i ,sklonili,, tu gde jesu.

Obrazovanje bi trebalo da se zasniva na objektivnim potrebama i mogućnostima osuđenih lica kako bi imalo efekta, jer prisilno obrazovanje, kao ni bilo koja druga prinuda ne može biti uspešno. Svaka vrsta obrazovanja, obuke i osposobljavanja za profesiju trebalo bi da počne od ispitivanja potreba i mogućnosti (finansijskih, organizacionih, kadrovskih) da se te potrebe 
zadovolje. Zbog čega onda ne pružiti priliku i osuđenicima da izraze svoje potrebe i interesovanja i saglase se sa tretmanom koji bi im, sigurni smo, na taj način efikasnije pomogao da promene neke svoje, bar radne, navike i stavove. Tretman bi trebalo bazirati na ispitanim potrebama, obrazovanju pre zatvora, psiho-fizičkim sposobnostima kao i na poznavanju potreba za zanimanjima u zatvoru i mogućnostima zaposlenja na slobodi. Zadatak organizovanja obrazovanja i obuke osuđenika nije nimalo jednostavan i nadamo se da će obuka savetnika iz Nacionalne službe za zapošljavanje koja je održana u martu 2013. u Kovačici olakšati posao motivisanja i aktiviranja osuđenika za stručno obrazovanje i obuku u zatvorskim ustanovama Srbije (www.vet-kpz.rs).

Prema podacima Helsinškog odbora za ljudska prava (2010) povratništvo u KPZ Sremska Mitrovica je oko 70\%. Veliki broj povratnika (među njima onih sa krivičnim delima nasilja i zloupotrebe droge) dovoljno govori o potrebi iznalaženja drugačijih, efikasnijih načina i oblika rada u zatvoru, ali i prihvata po izlasku iz penalnih ustanova. Iako se često recidivizam uzima kao indikator uspeha tretmana koji se primenjuje u toku izdržavanja zatvorske kazne, ostaje otvoreno pitanje koliko na tu veoma kompleksnu pojavu utiče: odmeravanje kazne, kategorizacija i klasifikacija u zatvoru (tretman koji se primenjuje, osoblje zatvora, neformalni sistem osuđenika koji se formira, kontakti sa spoljnim svetom) i postpenalni tretman, koji postoji samo na papiru.

Podaci o obrazovnoj strukturi osuđenika kojima raspolažemo dovoljno govore da se suočavamo sa problemima nepismenosti, elementarnim osnovnim obrazovanjem odraslih i visokim procentom nekvalifikovanih. Prema tome, obrazovanje u zatvorima bi trebalo usmeriti na elementarno opšte obrazovanje, sticanje osnovnih životnih veština i početnog stepena stručne osposobljenosti neophodne za uspešno uključivanje u rad. Taj nivo obrazovanja, tzv. funkcionalno osnovno obrazovanje odraslih, trebalo bi zaista prilagoditi odraslima umesto da se kao do sada obavlja po nastavnim planovima i programima redovne osnovne škole (razlika je bila samo u trajanju jer odrasli u toku jedne školske godine završavaju dva razreda). Novi oblici rada, metode i programi zahtevali bi nove udžbenike, andragoško-didaktički osposobljene nastavnike i instruktore (Knežić, Savić, 2012). 


\section{Istraživanje}

S obzirom na ulogu i značaj koju obrazovanje i edukativni programi u zatvoru mogu imati u procesu resocijalizacije, a na objektivno malo učešće osuđenika u postojećim obrazovnim aktivnostima u kazneno-popravnim ustanovama u Srbiji, krajem 2011. godine urađeno je istraživanje koje je imalo za cilj da ispita odnos osuđenika prema učestvovanju u obrazovanju u zatvoru.

Istraživanjem smo želeli da ispitamo da li kod osuđenika postoji motivacija za nastavak neke vrste obrazovanja i ukoliko postoji, koja vrsta obrazovnih sadržaja je u pitanju. Zanimalo nas je koji su razlozi zbog kojih osuđenici ne žele da učestvuju u edukativnim aktivnostima. Takođe nas je zanimalo mišljenje osuđenika o tome šta bi trebalo menjati u tretmanu, tj. koje aktivnosti bi trebalo uvesti.

Istraživanje je rađeno na uzorku od 260 osuđenika iz dve kaznenopopravne ustanove, Zabela (50 osuđenika) i Sremska Mitrovica (210 osuđenika). Uzorak je bio prigodan, tj. osuđenici su se dobrovoljno prijavili za učešće u istraživanju, a jedini uslov bio je da su pismeni.

Osuđenici su popunjavali kratak upitnik sa zatvorenim i poluotvorenim pitanjima. Jedan deo upitnika odnosio se na: starost osuđenika, obrazovanje, broj ranijih osuda. Pitanja u drugom delu upitnika odnosila su se na to da li bi osuđenik želeo da nastavi školovanje dok je na izdržavanju kazne, koju vrstu sadržaja bi voleo da uči, njegovo mišljenje da li obrazovanje utiče na promenu ponašanja i mišljenja, da li je osuđenik uposlen u KPZ-u i šta bi po njegovom mišljenju trebalo menjati u tretmanu osuđenika.

Uzorak je obuhvatio osuđenike starosti između 22 i 73 godine. Najviše osuđenika ima u kategoriji mlađeg srednjeg doba, između 25 i 40 godina $66 \%$, dok ih je najmanje u kategoriji preko 55 godina - 9\% (Tabela 1).

\section{Tabela 1.}

\begin{tabular}{|c|c|c|}
\hline Starost osuđenika & $\mathbf{N}$ & $\%$ \\
\hline do 25 & 26 & 10 \\
\hline 25 do 40 & 172 & 66 \\
\hline 40 do 55 & 39 & 15 \\
\hline preko 55 & 23 & 9 \\
\hline$\Sigma$ & 260 & 100 \\
\hline
\end{tabular}


U svođenju negativnih efekata učenja, koje se odvija između osuđenika, na najmanju moguću meru $76,2 \%$ osuđenika iz našeg uzorka starosti do 40 godina predstavlja značajnu ciljnu grupu za organizovanje najraznovrsnijih oblika obrazovanja.

S obzirom na nivo obrazovanja, u uzorku dominira kategorija osuđenika koja ima završenu srednju školu (treći ili četvrti stepen) - 40\%. Nepotpunu srednju školu ili samo osnovnu ukupno ima 46\% ispitanika, a nepotpunu osnovnu školu 10\% ispitanika. Procentualno najmanje zastupljena kategorija osuđenika je, kao i u opštoj populaciji, sa završenom višom školom ili fakultetom $-4 \%$.

U našem uzorku je oko $80 \%$ osuđenika bar jednom ranije bilo osuđivano, a čak 47\% više puta (između 2 i 13 puta).

$\mathrm{Na}$ pitanje da li bi želeli da nastave školovanje dok su u zatvoru, 55\% ispitanih osuđenika odgovara da bi želelo, dok 43\% ne želi.

Kada se ukrste podaci o želji za nastavkom školovanja i starost osuđenika (Tabela 2), dobija se značajna razlika $\left(\chi^{2}(3)=11,88, p<0.01\right)$, koja potiče od toga što među ispitanicima ispod 40 godina ima više onih koji bi želeli da nastave školovanje, dok među onima preko 40 godina ima manje takvih.

\section{Tabela 2.}

\begin{tabular}{|c|c|c|c|}
\hline \multirow{2}{*}{ do $\mathbf{2 5 g}$} & \multicolumn{3}{|c|}{ Da li žele nastavak školovanja } \\
\cline { 2 - 4 } & $\mathbf{d a}$ & ne & $\Sigma$ \\
\hline \multirow{2}{*}{$\mathbf{2 5}$ do 40g } & 17 & 8 & 25 \\
\hline \multirow{2}{*}{$\mathbf{4 0}$ do 55g } & $68 \%$ & $32 \%$ & $100 \%$ \\
\hline \multirow{2}{*}{ preko 55g } & 104 & 65 & 169 \\
\hline \multirow{2}{*}{$\Sigma$} & $61,5 \%$ & $38,5 \%$ & $100 \%$ \\
\hline & 15 & 24 & 39 \\
\hline & $38,5 \%$ & $61,5 \%$ & $100 \%$ \\
\cline { 2 - 4 } & 8 & 14 & 22 \\
\hline
\end{tabular}


Ovaj nalaz je i očekivan s obzirom na to da se u našem društvu, a u zatvorskoj sredini je to još izraženije, na obrazovanje još uvek gleda kao na obavezu dece i mladih, a ne na celoživotni proces učenja i razvoja. Ono što može da demotiviše osuđenike za učešće u obrazovanju jeste i to što pojedinci ne vide svrhu i korist od obrazovanja. Zbog toga je uloga zatvorskog osoblja od velikog značaja naročito za motivisanje starijih osuđenika za obrazovanje, pohađanje raznovrsnih tečajeva i predavanja na različite, za njih zanimljive i relevantne teme (npr. zdravlje, ishrana, istorija, religija).

U Tabeli 3. ukršteni su podaci o dužini kazne osuđenika i želji da nastave školovanje. Pokazalo se da među osuđenicima sa dužim zatvorskim kaznama, preko 5 i 10 godina, postoji znatno više onih koji žele da nastave školovanje $\left(\chi^{2}(3)=20,539, \mathrm{p}<0.01\right)$.

\section{Tabela 3.}

\begin{tabular}{|c|c|c|c|}
\hline \multirow{2}{*}{ Dužina kazne } & \multicolumn{3}{|c|}{ Da li žele nastavak školovanja } \\
\cline { 2 - 4 } & $\mathbf{d a}$ & ne & $\Sigma$ \\
\hline \multirow{2}{*}{ do 2 god } & 19 & 29 & 48 \\
\hline \multirow{2}{*}{$2-5$ god } & $39,6 \%$ & $60,4 \%$ & $100 \%$ \\
\hline \multirow{2}{*}{$\mathbf{5}-\mathbf{1 0}$ god } & 48 & 54 & 102 \\
\hline \multirow{2}{*}{ preko 10 god } & $47,1 \%$ & $52,9 \%$ & $100 \%$ \\
\cline { 2 - 4 } & 42 & 17 & 59 \\
\hline \multirow{2}{*}{$\boldsymbol{\Sigma}$} & $71,2 \%$ & $28,8 \%$ & $100 \%$ \\
\hline & 33 & 11 & 44 \\
\hline & $75 \%$ & $25 \%$ & $100 \%$ \\
\hline
\end{tabular}

Većina osuđenika koji su na odsluženju kazne koja traje preko pet godina učestvovanje u obrazovanju vide kao način da daju smisao ,pauziranju” od svakodnevnog života, a takođe i način da ispune dugo i sumorno zatvorsko vreme. Pa ako je i to razlog uključivanja u obrazovanje trebalo bi ga osmisliti i oživotvoriti kako zatvor ne bi postao ,skup način da se loši ljudi učine još gorim” (Home Office, 1988, prema Wilson, Reuss, 2000). 
Odgovore svih osuđenika na pitanje zašto žele da nastave obrazovanje razvrstali smo u pet kategorija koje su navedene prema redosledu zastupljenosti:

- doživotno obrazovanje, rad na sebi, želja za obrazovanjem, usavršavanje, želja za novim znanjem;

- mogućnost zaposlenja po isteku kazne;

- kvalitetno korišćenje slobodnog vremena;

- završetak započetog školovanja i

- želja za promenom posla.

Zanimljivo je da je motiv za obrazovanjem koji je najzastupljeniji - rad na sebi ili neka vrsta želje za usavršavanjem, a da su tek posle njega zastupljeni konkretniji, praktičniji motivi kao što je pronalaženje posla, promena posla ili završetak započetog školovanja.

Najčešći razlog osuđenika koji ne žele dalje da se obrazuju jeste zadovoljstvo postignutim nivoom obrazovanja i znanjima koja već poseduju (33\% odgovora). Jedan deo osuđenika navodi da nema motiva za dalje školovanje, da ne žele i ne treba im dalje obrazovanje (24\% odgovora). Grupa osuđenika kao razlog navodi to što su već stari da se dalje školuju, iako je većina njih u tridesetim i četrdesetim godinama $\mathrm{i}$ ima još dobar deo radnog veka pred sobom (18\% odgovora). Preostali motivi koje navode mogli bi se svrstati u objektivne ( $25 \%$ odgovora) - nepostojanje uslova u zatvoru, dužina preostale kazne i bolest ili invaliditet.

Većina ispitanih osuđenika - 75\%, smatra da obrazovanje utiče na promenu ponašanja i mišljenja, spram 13\% koji ne misle tako. Moglo bi se reći da većina ispitanih osuđenika vidi obrazovanje kao mogući faktor promene u životu, ali da je veoma mali broj njih spreman da iskoristi tu mogućnost za promenu. Kao što smo ranije pomenuli, preko $50 \%$ ispitanih osuđenika bi želelo da se uključi u neki vid edukacije, što je broj koji mnogostruko premašuje realan broj osuđenika uključenih u edukaciju u zavodima. Ako kao jedan od razloga izuzmemo davanje socijalno poželjnih odgovora, ostaje mogućnost da osuđenici ne vide ponuđene edukativne programe kao odgovarajuće njihovom potrebama, odnosno ne vide direktnu vezu tako koncipiranog obrazovanja sa životom na slobodi i mogućnošću zapošljavanja ili unapređivanja sebe i svojih sposobnosti i znanja.

$\mathrm{Na}$ pitanje sa ponuđenim odgovorima šta bi menjali u tretmanu osuđenici su se najviše opredeljivali za odgovor - uposliti sve (33\% odgovora), zatim za odgovor - organizovati obrazovanje i osposobljavanje za zanimanje ( $12 \%$ odgovora), pa organizovati kulturne, sportske, zabavne aktivnosti (11\% odgovora) i na kraju organizovati predavanja na neke teme ( $9 \%$ odgovora). 
Osuđenici koji smatraju da bi trebalo organizovati kulturne, sportske, zabavne aktivnosti navode: sportska takmičenja, turnira, pozorišnih predstava, bioskopa, koncerata, sekcija (šahovska, dramska, muzička). Neke od ovih aktivnosti već i postoje u zavodima, pri čemu za sportske postoji i najveće interesovanje i najveća uključenost osuđenika. Najveći broj ispitanika se opredeljuje za više odgovora (35\%).

Iz navedenih rezultata istraživanja vidljivo je da postoje pozitivni pokretači na obrazovanje i u zatvoru koji mogu podstaći osuđenike da uče s namerom da na neki način nadoknade propušteno u svom dotadašnjem obrazovanju i da bar izvuku neku korist od neslobode. Motivacija i raznolikost mogućnosti obrazovanja, više nego na drugim mestima i u drugim okolnostima, značajan su preduslov za uspešno obrazovanje u zatvoru. Uloga osoblja u zatvoru, pogotovo službi za tretman i obuku, od velike je važnosti kada je u pitanju informisanost osuđenika o pravima i mogućnostima obrazovanja i obuke. Poznato je da obrazovna motivacija zavisi od socio-demografskih karakteristika i da se njihovim promenama u različitim periodima životnog ciklusa menjaju i interesovanja i motivi za obrazovanjem. Programski sadržaji bi trebalo da prate te promene, potrebe i interesovanja pojedinaca. Jedino u takvim okolnostima čovek može i kada je u zatvoru, imati motivaciju i interesovanje za sticanje znanja i kvalifikacija, što mu po izlasku iz zatvora može pomoći prilikom zaposlenja. Osećanja poniženja, sumnja u vlastite sposobnosti, nedostatak motivacije, bezvoljnost, umor, ograničenost na osoblje zatvora, mogu doprineti neuključivanju u proces obrazovanja i osposobljavanja.

\section{Zaključna razmatranja}

Prednosti programa obrazovanja u zatvorima čine se nesporne imajući u vidu dobrobit svakog od pojedinaca uključenog u njega kao i dugoročnu korist za celo društvo koje će imati produktivnog člana zajednice. Zakonom (ZIKS) je prilično dobro određena uloga i značaj obrazovanja, obuke i osposobljavanja, ali nažalost, tih oblika aktivnosti je veoma malo u penalnim ustanovama. Zakonsko pravo na obrazovanje trebalo bi pretočiti u smisleno obrazovanje uporedivo sa onim van zatvora, koje će zadovoljiti potrebe osuđenika u zatvoru i nakon izlaska iz njega.

Obrazovno i svrsishodno radno angažovanje osuđenika načini su ispunjavanja svrhe zatvorske kazne, a ti oblici tretmana su u praksi nesrazmerni sa ulogom koju imaju, potrebama društva i pojedinca u ostvarivanju cilja kažnjavanja, koji se ne zasniva samo na represiji i očuvanju reda i kontrole. 
Stoga bi trebalo:

- uspostaviti bolju saradnju između pojedinih ministarstava (finansija, pravosuđa, prosvete, kulture, rada i socijalne zaštite) kao i zatvora i lokalne zajednice;

- utvrditi obrazovni nivo i ispitati obrazovne potrebe osuđenika kao i potrebe za određenim zanimanjima u zatvoru i na tržištu rada, pa u zavisnosti od sposobnosti i interesovanja osuđenika i trajanja njihove kazne odrediti vrstu osposobljavanja;

- stručno planirati obrazovne aktivnosti osuđenika. Planove i programe osposobljavanja treba osavremeniti i prilagoditi promenama kako bi bili u skladu s aktuelnim stanjem u praksi;

- motivisati osuđenike za uključivanje u obrazovanje i stručno osposobljavanje organizovanjem različitih kampanja, jer je poznato da su osuđenici veoma heterogena grupa, različitog socijalnog porekla, nivoa obrazovanja, porodičnog statusa, vrste krivičnog dela zbog kojeg su u zatvoru;

- poboljšati kadrovsku strukturu, obučiti i osposobiti osoblje za rad u specifičnoj sredini kao što je zatvor i sa još specifičnijom populacijom kao što su osuđenici. Vaspitačima treba vratiti ugled koje to ime zaslužuje, a ne da se njihov rad svodi na povremene kratke razgovore, čitanje i cenzuru pisama ili, kako misle osuđenici, na cinkarenje.

Podaci istraživanja ukazuju da postoje osuđenici koji žele da učenjem novih sadržaja ispune slobodno vreme. Od osoblja i osuđenika se saznaje da su sportsko-rekreativne i kulturno-zabavne aktivnosti zapostavljene, a u njima bi većina osuđenih učestvovala. Kod nas su razmišljanja o obrazovanju u zatvoru još uvek rigidna jer ga jedni poistovećuju sa učenjem pisanja i čitanja, prisećajući se analfabetskih tečajeva, a drugi nipodaštavaju njegov značaj kada su u pitanju oni koji su se „ogrešili,, o zakone. Iluzorno je očekivati rezultate, ako država ne vidi u obrazovanju mehanizam promene i sredstvo kojim će pomoći reintegraciju osuđenika u društvo. 


\title{
PRISON EDUCATION: FROM THE RIGHT TO REALISATION ${ }^{6}$
}

\begin{abstract}
- Abstract -
Increasing number of returnees, congestion of prisons and bad conditions in prisons do not indicate that the society is coping with delinquency in best possible way. Since 1980s in most western countries and in our country also the concept of social rehabilitation is being criticised for not bringing a drop in the crime rate or recidivism. Problem which societies are facing is how to prepare prisoners, while they still serve a sentence, for integration into society once they have left prison. To achieve this goal education can play a very important role. In this article we will treat different aspects of prison education: how it is regulated by the state and what is its purpose, what is the current situation in our and other countries for prisoners to embrace their right to education, what are the obstacles for education in prisons. One of the main preconditions for implementation and success of education programmes in prisons is the motivation of inmates to participate. We will show one part of the study conducted in two correctional facilities (Požarevac and Sremska Mitrovica) on motivation of prisoners for education and their educational needs.
\end{abstract}

Keywords: education, prisoners, recidivism, rehabilitation, prison environment.

6 Article presents the results of the project „Crime in Serbia: phenomenology, risks and possibilities of social intervention" (Number 47011) financed by Ministry of education, science and technological development of Republic Serbia (2011-2014). 


\section{Literatura}

- Boshier, R. (1985). Adult Education: Motivation of Participants, Oxford: L.E.E Pergamon Press.

- Bozos, A. \& Hausman, J. (2004). Correctional Education as a Crime Control Program. UCLA School of Public Policy and Social Research, Department of Policy Studies.

- Cecil, D., Drapkin, D. A., MacKenzie, D. L., \& Hickman, L. J. (2000). The Effectiveness of Adult Basic Education and Life-Skills Programs in Reducing Recidivism: A Review and Assessment of the Research. Journal of Correctional Education, 51(2), p. 207-226.

- European Conference on Prison Education, „Pathways to inclusion - Strengthening European Cooperation in Prison Education and Training”, Budapest, 22-24 February 2010. http://ec.europa.eu/ education/grundtvig/doc/conf11/a7report.pdf.

- Francis, N.T. (2010). The Effect of Education Programs on Prisoner Recidivism in Michigan.Northern Michigan University.

http://www.nmu.edu/sites/DrupalEducation/files/UserFiles/Files/PreDrupal/SiteSections/Students/GradPapers/Projects/Nelson_Taryn_ MP.pdf.

- Gaes, G. (2008). The Impact of Prison Education Programs on PostRelease Outcomes. Paper presented at the Reentry Roundtable on Education, John Jay College of Criminal Justice, New York.

- Gehring, T. (2000). Recidivism as a measure of correctional education program success. Journal of Correctional Education, 51, p. 197-205.

- GHK (2011). Prison education and training in Europe - a review and commentary of existing literature, analysis and evaluation. Directorate General for Education and Culture, European Commission.

- Harer, M.D. (1994). Recidivism among federal prison releasees in 1987: A preliminary report. Washington DC: Federal Bureau of Prisons.

- Harer, M.D. (1995). Prison Education Program Participation and Recidivism: A Test of the Normalization Hypothesis. Washington, DC: Federal Bureau of Prisons, Office of Research and Evaluation.

- Home Office (1988). Punishment, Custody and the Community. London: HMSO.

- Hull, K., Forrester, S., Brown, J., Jobe, D., McCullen, C. (2000). Analysis of Recidivism Rates for Participants of the Academic/ 
Vocational/Transition Programs Offered by the Virginia Department of Correctional Education. Journal of Correctional Education, 51(2), p. 256-261.

- Izveštaj o radu Uprave za izvršenje krivičnih sankcija za 2011. http://www.uiks.mpravde.gov.rs/cr/articles/izvestaji-i-statistika/.

- Izveštaj o radu Uprave za izvršenje krivičnih sankcija za 2010. http://www.uiks.mpravde.gov.rs/cr/articles/izvestaji-i-statistika/.

- Kling J.R.(2006). Incarceration, Length, Employment, and Earnings. The Brookings Institution and National Bureau of Economic Research. http://www.nber.org/ kling/494.pdf.

- Knežić, B. (2001). Obrazovanje i resocijalizacija - metode merenja, Beograd, Zavod za udžbenike i nastavna sredstva.

- Knežić, B., Savić, M. (2012). Obrazovanje iza rešetaka. U Kron, L. (ur.) Delikt, kazna i mogućnosti socijalne profilakse. Institut za kriminološka i sociološka istraživanja, Beograd, str. 179-193.

- Kosmidou, A. (2011). Education behind Bars: The Case of Sweden. Andragoške studije, br. 1, str. 119-133.

- Lewis, J. (2006). Correctional education: Why it is only promising, Journal of Correctional Education, 57(4), p. 286-296.

- MacKenzie, D.L. (2006). What Works in Corrections: Reducing the Criminal Activities of Offenders and Delinquents. Cambridge University Press.

- Ripley, P. (1993). Prison Education Role in Challenging Offending Behaviour. Mendip Papers MP 047.

- Soferr, S. (2006). Prison Education: Is It Worth It? Corrections Today, Vol. 68, Issue 6.

- Steurer, S.J.\& Smith,L.G.(2003). Education Reduces Crime: ThreeState Recidivism Study Executive Summary, Correctional Education Association. www.ceanational.org/PDFs/EdReducesCrime.pdf.

- Stevanović, Z. (2012). Zatvorski sistem u svetu. Institut za kriminološka i sociološka istraživanja Beograd.

- Vacca, J.M. (2004). Educated Prisonersa Are Less Likely To Return to Prison, The Journal Of Correctional Education, 55(4), p. 297-305.

- Wade, B. (2007). Studies of correctional education programs. Adult basic Education and Literacy Journal, 1(1), p. 27-31.

- Walmsley, R. (2012). World Prison Population List ( $9^{\text {th }}$ edition).

- Wilson, D., Reuss, A. (2000). Prison(er) Education. Waterside Press.

- Zakon o izvršenju krivičnih sankcija i Izmene zakona o izvršenju 
krivičnih sankcija, Službeni glasnik RS, br. 85/2005 i br. 72/2009.

- Zatvori u Srbiji. Praćenje reforme zatvorskog sistema u Srbiji (2010). Helsinški odbor za ljudska prava u Srbiji.

- UN Human Rights Council (2009). The right to education of persons in detention: report of the Special Rapporteur on the Right to Education, Vernor Muñoz, available at: http://www.refworld.org/ docid/4a00419d2.html [accessed May 2013].Zarfa Hrnjić Kuduzovic ${ }^{7}$

7 Doc. dr. Zarfa Hrnjić Kuduzović, Fakultet političkih nauka, Univerzitet u Sarajevu 